\title{
The Effectiveness and Safety of Vermi-Versus Conventional Composting of Human Feces with Ascaris suum Ova as Model Helminthic Parasites
}

\author{
Geoff B. Hill ${ }^{1}$, Cecilia Lalander ${ }^{2} \&$ Susan A. Baldwin ${ }^{3}$ \\ ${ }^{1}$ Department of Geography, University of British Columbia, British Columbia, Canada \\ ${ }^{2}$ Institutionen för energi och teknik, Sveriges lantbruksuniversitet (SLU), Uppsala, Sweden \\ ${ }^{3}$ Chemical and Biological Engineering, University of British Columbia, British Columbia, Canada
}

Correspondence: Geoff B. Hill, Department of Geography, University of British Columbia, British Columbia, Canada. E-mail: geoff.hill@geog.ubc.ca

Received: January 22, 2013 Accepted: February 25, 2013 Online Published: March 4, 2013

doi:10.5539/jsd.v6n4p1

URL: http://dx.doi.org/10.5539/jsd.v6n4p1

\begin{abstract}
Composting toilets have been promoted for management of human waste at remote sites in parks and alpine areas of recreation, but they may not be effective for producing a stable and safe end product. Vermicomposting has been shown to result in a more degraded final product but its effectiveness for pathogen destruction was unclear due to conflicting information in the literature. This study sought to resolve the debate on whether or not vermicomposting could produce a hygenic end product that would be safe for disposal locally. Vermicomposting was tested for destruction of the model pathogens, helminthic parasites, in an experiment with highly concentrated and viable Ascaris suum (2626 $1306 \mathrm{ova} / \mathrm{g}, 61.6 \pm 8.7 \%$ viable) inoculated into fecal matter and coir (30:70 ratio) with and without Eisenia fetida worms. After 90 days at $19 \pm 3{ }^{\circ} \mathrm{C}$ six, eight, and 12 worms were found alive with no significant difference between treatments or through time found in TS\% (12-15\%), ova concentration and ova viability. A 100 times reduction in the concentration of Escherichia coli resulted from the worm treatment versus the control. Significantly higher nitrate $\left(22735 \pm 4741 \mathrm{mg} / \mathrm{kg} \mathrm{NO}_{3}{ }^{-}\right)$and lower $\mathrm{pH}(\mathrm{pH}$ $4.60 \pm 0.01)$ were found in the treatment as compared to the control $\left(5078 \pm 2167 \mathrm{mg} / \mathrm{kg} \mathrm{NO}_{3}{ }^{-}\right)(\mathrm{pH} 6.56 \pm 0.30)$. Despite these improvements in fecal matter processing, vermicomposting was found ineffective at reducing Ascaris suum ova concentration and viability. Decentralized vermicomposting can efficiently stabilize and mature fecal matter; however prior to unrestricted end product use, an additional sanitation step is necessary.
\end{abstract}

Keywords: vermicomposting, human waste, Ascaris suum, helminthic parasites, E. coli, nitrate

\section{Introduction}

Management of human waste using waterless technology is often the only option in remote locations. Additionally, composting toilets are being adopted in some urban areas, since they are perceived as safe and effective, although there is little on going monitoring to prove this. The ideal onsite human waste treatment system would be a continuous flow, one step process to produce stabilized, sanitized and mature end products that can be handled without health risks and disposed onsite without environmental impacts, bringing about, at very low cost and risk, production of a soil amendment that could be used for rehabilitation projects. The waterless and waste reuse aspects of composting toilets make them an attractive sustainable technology.

Despite popular perception, Hill and Baldwin (2012) indicate that composting toilets fail to deliver these objectives. Urine diverting dehydrating toilets (UDDTs) divert urine, evaporate moisture, and require ash amendment in order to reduce pathogens through desiccation and alkalization and are considered to be an improved design over latrine composting toilets. Despite the focus on pathogen destruction over stabilization, $31 \%$ of samples from Bolivian UDDTs that met World Health Organization (WHO) guidelines for UDDTs (high pH, low moisture, and long storage times), still contained viable Ascaris lumbricoides ova indicating that UDDT systems are not reliable sanitization systems (McKinley, Parzen, \& Guzmán, 2012). 
Although vermicomposting has not been approved by Canadian or US federal agencies as a pathogen reduction and stabilization pathway, it has been shown that vemicomposting (Eastman et al., 2001) and urine diverting vermicomposting toilets (Hill \& Baldwin, 2012) may have the capability to deliver on all of these objectives (stabilization, maturation, and sanitization). By diverting urine, fecal matter and toilet paper become a suitable feedstock for decentralized vermicomposting, a process that was shown, by Hill and Baldwin (2012), to produce sanitized (low E. coli), mature (Solvita ${ }^{\circledR} 4 \pm 0$ ) and stable (VS $60 \pm 10 \%$ ) solid end product from human excrement, as has been shown similarly in numerous other studies including Bajsa, Nair, Mathew, Ho (2003) (sewage sludge), Yadav, Hait, Tare (2007) (source separated fecal matter), Benitez, Nogales, Elvira, Masciandaro, Ceccaniti (1999) (sewage sludge), and others for numerous animal manures and industrial wastes as reviewed by Sinha, Herat, Bharambe (2009) and Edwards, Arancon, Sherman (2011). Vermicomposting toilet systems have, moreover, been shown to be safer, easier and less expensive to manage than traditional composting toilets (Hill \& Baldwin, 2012). Diverted urine can be discharged directly to shallow septic fields for rapid assimilation and pathogen attenuation by active soil microbes and plant roots or collected, stored, and utilized as fertilizer in crop production (Del Porto \& Steinfeld, 2000). One objective of this study was to directly compare the efficacy of vermicomposting with that of composting without worms on the same feces starting material under identical conditions. End products were compared by measuring common composting quality indices.

Postulated mechanisms for pathogen destruction by earthworms include: selective predation/ consumption (Edward \& Bohlen, 1996; Kumar \& Shweta, 2011); mechanical destruction through action of gizzard (Edwards \& Subler, 2011); microbial inhibition through humic and coelomic acids or other enzymes secreted within the digestive tract and extracellular and within gut (Edwards \& Subler, 2011); stimulation of microbial antagonists including the ones of the Streptosporangium and Pseudomonas genera (Kumar \& Shweta, 2011); and indirectly through stimulation of endemic or other microbial species which outcompete, antagonize, or otherwise destroy pathogens (Edwards \& Subler, 2011).

In addition to examining reduction of pathogens such as E. coli we chose to study also the fate of helminthic parasites. Ascaris lumbricoides ova are one of the most resistant human parasites commonly found in fecal matter (Eastman et al., 2001; Bowman et al., 2006; Jimenez-Cisneros \& Maya-Rendon, 2007). The ova shells are highly resistant to salts, chemicals, desiccation, acids, bases, oxidants and reductive agents (Jimenez-Cisneros \& Maya-Rendon, 2007). Bean, Hansen and Margolin (2007) found that $\mathrm{pH}$ adjustment up to 12 for two to 72 hours had no effect on ova viability compared to controls in neutral $\mathrm{pH}$. Ammonia has been shown to have greater destructive potential than $\mathrm{pH}$ adjustment alone (Mendez-Contreras, Jimenez, \& Maya, 2004) presumably due to the permeability of the ova shell to gases (Jimenez-Cisneros \& Maya-Rendon, 2007). Temperatures greater than $40{ }^{\circ} \mathrm{C}$ (with residence times determined by temperature and type of process) are also utilized to destroy ova (Jimenez-Cisneros \& Maya-Rendon, 2007). Thermophilic aerobic digestion at $48{ }^{\circ} \mathrm{C}$ for 30 days achieved $78 \%$ efficiency in helminthic ova reduction from 4.5 to $<1$ ova/10g TS (Gantzer, Gaspard, \& Galvez, 2001). Despite Ascaris ova defenses, Eastman et al. (2001) reported that vermicomposting could reduce ova to below acceptable EPA limits. Based on Ascaris ova superior chemical defenses and resistance to aerobic processes, it seems unlikely that a single passage (12-20 hours residence time (Wood, 1995)) through the gut of the earthworm would be adequate to digest the three layers of protective ova shell and accomplish a reduction in viability or ova concentration. It is possible that chitinase excreted within the earthworm gut (Wood, 1995) could begin the degrading the ova's middle chitin based protein layer (Jimenez-Cisneros \& Maya-Rendon, 2007), which confers mechanical resistance and prevents passage of material into the cell, but it seems likely that multiple passes or considerable subsequent degradation outside the gut of the worm would be necessary to accomplish significant decrease in ova viability or complete destruction and decrease in concentration. Bowman et al. (2006) found holes in Eastman et al. (2001) methodology, which cast doubt on the validity of these earlier results. Nevertheless, if vermicomposting were demonstrated to eradicate Ascaris ova from human excrement, the process could be relied upon as the sole sanitization step in a decentralized treatment system of human waste in which the residual organic matter could be reused for land application. To resolve this controversy, the laboratory experiments were designed to also evaluate the effect of vermicomposting on helminthes by spiking the model helminthic parasite Ascaris suum ova into the fecal matter. Although Ascaris suum are parasites that more commonly infect pigs, they are the closest relative to A. lumbricoides, and the ova of both species are similarly resistant to destruction. Composting quality variables were recorded along with Ascaris suum concentration and viability to test the effectiveness and safety of vermicomposting in comparison with composting without worms. 


\section{Method}

Fecal matter from two male volunteers was collected over the course of two weeks and stored at $4{ }^{\circ} \mathrm{C}$ for 2 weeks prior to initiating the experiments. Four kilograms of fecal matter was saturated with distilled water, drained over a 24 hour period, inoculated with three million Ascaris suum ova purchased from Excelsior Sentinel Inc. (Trumansburg, NY) and mixed into four kilograms of damp coconut coir, making a 50:50 fecal:coir wet weight feedstock. Coir was chosen as it is commonly used in vermiculture in Europe (Anbuselvi, 2009). It has little nutritional value but considerable water holding capacity which makes it a great bulking agent for fecal matter, as was discovered in pre-experiment trials (Anbuselvi, 2009). In addition to testing for Ascaris suum concentration and viability, the feedstock (before being added to the coir) was sampled for a variety of physicochemical variables to measure decomposition and maturity in end products (Table 1). Feedstock and end products were vacuum sieved with a $250 \mu \mathrm{m}$ sieve and volatile solids (\%) were calculated on both fractions. All analyses, unless otherwise stated, were conducted by Benchmarks Labs (Calgary, AB).

The feedstock was initially used in an experiment that was abandoned after 48 hours after the majority of the worms died. Dead earthworms were removed; the material was recombined, thoroughly mixed, and placed at 4 ${ }^{\circ} \mathrm{C}$ for 3 days while modifications to experimental design were made.

Table 1. Parameters tested and test names/ description or formulae, used to evaluate vermicomposting effects on Ascaris suum. Parameters tested by Benchmark Labs (Calgary, AB) denoted with *

\begin{tabular}{|c|c|c|}
\hline Parameter & Test Name / Description or Formula & Units \\
\hline $\begin{array}{l}\text { Percent total solids } \\
\quad(\mathrm{TS} \%)^{*}\end{array}$ & APHA Method 3540B & $\%$ \\
\hline $\begin{array}{l}\text { Percent volatile solids } \\
\text { (VS\%)* }\end{array}$ & APHA Method 2540 & $\%$ \\
\hline $\begin{array}{l}\text { Percent volatile } \\
\text { solids }>250 \text { um }\end{array}$ & APHA Method 2540 with sieve fraction $>250 \mathrm{um}$ & $\%$ \\
\hline $\begin{array}{l}\text { Percent volatile solids } \\
<250 \text { um }\end{array}$ & APHA Method 2540 with sieve fraction $<250 \mathrm{um}$ & $\%$ \\
\hline $\begin{array}{l}\text { Ammonium-N } \\
\left(\mathrm{NH}_{4}^{+}-\mathrm{N}\right)^{*}\end{array}$ & Mod. ASTM D6919 (ion chromatography) & $\mathrm{mg} / \mathrm{kg}(\mathrm{ds})$ \\
\hline $\begin{array}{l}\text { Free ammonia-N } \\
\qquad\left(\mathrm{NH}_{3}-\mathrm{N}\right)^{*}\end{array}$ & {$\left[\mathrm{NH}_{3}\right]=\left[\mathrm{NH}_{4}\right]_{10^{9 \cdot 3-\mathrm{pH}}}\left(\right.$ at $\left.20{ }^{\circ} \mathrm{C}\right)$} & $\mathrm{mg} / \mathrm{kg}(\mathrm{ds})$ \\
\hline $\mathrm{pH}^{*}$ & $\begin{array}{l}\text { Cold water shake } 1: 2 \text { sample:water, followed by measurement with } \\
\text { VWR symphony pH probe at } 25^{\circ} \mathrm{C}\end{array}$ & - \\
\hline E. coli ${ }^{*}$ & $\begin{array}{l}\text { Cold water shake extraction followed by USEPA Approved Method } \\
1604 \text {, with only E. coli reported by membrane filtration using a } \\
\text { simultaneous detection technique }\end{array}$ & $\mathrm{CFU} / \mathrm{g}(\mathrm{ds})$ \\
\hline Nitrate $\left(\mathrm{NO}_{3}^{-}\right)^{*}$ & APHA Method 4110A & $\mathrm{mg} / \mathrm{kg}(\mathrm{ds})$ \\
\hline $\begin{array}{l}\text { Ascaris sp. ova } \\
\text { concentration* }\end{array}$ & As per Kato et al. 2003 with minor modifications & $\# / g$ \\
\hline $\begin{array}{l}\text { Ascaris sp. ova } \\
\text { viability* }\end{array}$ & As per Kato et al. 2003 with minor modifications & $\%$ viable \\
\hline Zinc $(\mathrm{Zn})^{*}$ & Mod. EPA 3050A (Digestions), Mod. EPA 6020 (ICPMS) & $\mathrm{mg} / \mathrm{kg}(\mathrm{ds})$ \\
\hline Phosphorus $(\mathrm{P})^{*}$ & Mod. EPA 3050A (Digestions), Mod. EPA 200.7 (ICPOES) & $\mathrm{mg} / \mathrm{kg}(\mathrm{ds})$ \\
\hline $\begin{array}{l}\text { Total Kjeldahl Nitrogen } \\
\text { (TKN)* }\end{array}$ & Watson, M. et al. (2003) & $\mathrm{mg} / \mathrm{kg}(\mathrm{ds})$ \\
\hline
\end{tabular}

To increase worm survival, the original feedstock was placed into six $500 \mathrm{~mL}$ glass jars upon a bedding of $150 \mathrm{~g}$ of damp coir, diluting it from its 50:50 fecal:coir ratio to 30:70. Fifteen mature Eisenia sp. worms, were added to three treatment jars creating a worm density of $\sim 0.013$ grams earthworm per gram material. The remaining three jars were left as controls. Permeable geotextile was placed on the top of the jars and sealed with threaded rims. The jars were placed in a stratified pattern in a rectangular plastic container. A Hobo ${ }^{\circledR}$ air temperature and relative humidity logger were added to the plastic container and the container was placed into a covered, insulated, temperature regulated $\left(18-22{ }^{\circ} \mathrm{C}\right)$ and humidified (80-90\%) chamber. After 90 days, counting the number of worms and the cocoon density determined the health of the worms. Cocoons are formed as a result of reproduction and their number informs on reproductive health of the worms. Then, the experiment jars were sent by overnight courier to Benchmark Labs for testing. Material was thoroughly mixed before sub-sampling. Upon 
completion of testing, Benchmark Labs shipped samples back to the authors for storage at $4{ }^{\circ} \mathrm{C}$. After 15 days, samples were sent back to Benchmark Labs for total nitrogen and phosphorus testing. Coir was also sampled at this time for the full suite of tests. Remaining sample was kept in the fridge at $4{ }^{\circ} \mathrm{C}$.

To further investigate if the conversion of ammonia to nitrate was due to microbial activity in the composting material, marker genes for total bacteria and bacterial ammonia oxidation were quantified. Genomic DNA was extracted from duplicate $10 \mathrm{~g}$ wet weight samples using the MoBio ${ }^{\circledR}$ PowerSoil DNA extraction kit (MoBio Labs, Solana Beach, CA) according to the manufacturer's instructions three weeks after final sampling. Total nucleic acid concentration and DNA purity were measured using a NanoDrop ${ }^{\circledR}$ ND-2000 UV-Vis Spectrophotometer (NanoDrop Technologies, Wilmington, DE). Appropriate dilutions with sterile nucleotide-free water were carried out so that all DNA samples were the same concentration. Total bacteria $16 \mathrm{~S}$ rRNA and the bacterial ammonia monooxygenase structural gene, amo $A$, were quantified using primers Bac27F 5' AGAGTTTGATCCTGGCTCAG 3'(Lane et al., 1985); Bac519R 5' GNTTTACCGCGGCKGCTG 3'; and amoA-1F; 5'-GGGGTTTCTACTGGTGGT; amoA-2R; 5'-CCCCTCKGSAAAGCCTTCTTC (Rotthauwe, Witzel, \& Liesack, 1997), respectively. Quantitative polymerase chain reaction with SsoAdvanced ${ }^{\text {TM }}$ SYBR $^{\circledR}$ Green Supermix (Bio-Rad Labs Inc., Hercules, CA) and primers concentrations of $200 \mathrm{nM}$ was performed on a CFX Connect ${ }^{\mathrm{TM}}$ Real-Time PCR Detection System (Bio-Rad) with reaction conditions: $98^{\circ} \mathrm{C} 2 \mathrm{~min}$; up to 40 cycles of $98{ }^{\circ} \mathrm{C} 5 \mathrm{sec}$; annealing temperature of $55^{\circ} \mathrm{C}$ (total bacteria) or $60{ }^{\circ} \mathrm{C}$ (amoA) $30 \mathrm{sec}$; with a final melting curve at $65-95{ }^{\circ} \mathrm{C}$ at $0.5{ }^{\circ} \mathrm{C}$ increments of $2 \mathrm{sec}$. Reactions were performed in triplicate and all amplicons produced only one melting curve peak. The average number of cycles required for each sample to reach a threshold relative fluorescence unit was recorded (Cq value).

ANOVA tests were used to evaluate between treatments and controls after checking univariate assumptions, which were met in all cases.

\section{Results and Discussion}

An average temperature of $19 \pm 3{ }^{\circ} \mathrm{C}$ was measured through the duration of the 90 day experiment. The temperature tolerance for Eisenia sp. is between $0-35^{\circ} \mathrm{C}$ with an optimum between $20-25{ }^{\circ} \mathrm{C}$ (Neuhauser, Loehr, \& Malecki, 1988). The relative humidity in the covered chamber averaged $95 \pm 6 \%$, which assisted in the maintenance of soil moisture favored by earthworms without requiring frequent manual watering to replace water lost through cellular respiration and evaporation.

The measured starting worm density was $0.013 \mathrm{~g}$-worm $/ \mathrm{g}$-material $(15$ worms, average $0.3 \mathrm{~g} / \mathrm{worm}$, in $350 \mathrm{~g}$ of wet material) and is within the range of worm densities $0.005-0.05 \mathrm{~g}$-worm/g-material found to successfully sanitize sewage sludge and fecal matter producing stable and mature end product in 8-9 weeks during experimental trials (Benitez, 1999; Yadav et al., 2007). Worm count by the end of the 90 day experiment had dropped to $8.7 \pm 3.0$ from 15; nonetheless, the treatment effect of vermicomposting was considered sufficient as the sample with the lowest final worm density $(0.007 \mathrm{~g} / \mathrm{g})$ was still higher than that found sufficient in other studies (Benitez et al., 1999; Yadav et al., 2007).

The cocoon density $(0.069 \pm 0.087$ cocoons/gram total feedstock (Table 2$)$ is in the middle of a considerable range of cocoon densities found in other experiments including Yadev et al. (2007) where 0.0026-0.0032 cocoons/g feedstock were found from 30 worms placed into $40 \mathrm{~kg}$ feedstock for 4 months, and Sangwan, Kaushik, Garg (2008) who found 0.42-1.36 cocoons/g feedstock (from 5 worms placed into $150 \mathrm{~g}$ feedstock in 1 $\mathrm{L}$ containers for 13 weeks). Adequate nutrition is required to support growth and reproduction in earthworms (Sangwan et al., 2008) and the cocoon density found here can be interpreted as an indicator of adequate nutrition and affirmation of the vermicomposting process in the treatment jars (Dominguez \& Edwards, 2011). Nevertheless, being a closed experiment, the process was far from optimized; Eisenia sp. can produce 0.35 cocoons/worm/day (Dominguez \& Edwards, 2011), which would equate to a cocoon density of 1.4 cocoons/g material if the rate were maintained throughout the 90 day experiment.

The TS content of the feedstock, coir, treatment and control were all between $12-15 \%$, which is within the optimum range (75-90\% moisture content) for vermicomposting (Neuhauser et al., 1988) (Table 2). Domínguez and Edwards (Domínguez \& Edwards, 1997) suggested the optimum moisture be between 80-90\%. End product from non-bulked commercial vermicomposting toilets- which sustained adequate worm density $(0.03 \pm 0.04$ g-worm/g-material), reduced E. coli to $200 \mathrm{CFU} / \mathrm{g}$, and produced mature, stable, high density $\left(850 \mathrm{~kg} / \mathrm{m}^{3}\right)$ vermicompost - was considerably drier, a factor which is important in order to prevent anaerobic conditions $\left(27 \pm 10 \%\right.$ TS) (Hill \& Baldwin, 2012). However, the high lignin content $(30 \%)$ and low density $\left(70-80 \mathrm{~kg} / \mathrm{m}^{3}\right)$ of the coconut coir bulking agent likely maintained oxygen transport preventing anaerobic conditions from developing (Anbuselvi, 2009). As desired, there was no significant difference in TS between treatment and 
control eliminating any effect or interaction moisture content may have had on decomposition or pathogen destruction.

Table 2. Feedstock, coir, starting material, treatment, and control means and standard deviations for parameters tested in determination of effect of vermicomposting on Ascaris suum

\begin{tabular}{|c|c|c|c|c|c|c|}
\hline $\begin{array}{l}\text { Parameter } \\
\text { (units) }\end{array}$ & $\begin{array}{c}\text { Feedstock } \\
\text { (mean } \pm \text { SD) }\end{array}$ & $\begin{array}{c}\text { Coir } \\
(\text { mean } \pm \text { SD) }\end{array}$ & $\begin{array}{c}\text { Starting Avg }^{+} \\
(\text {mean } \pm \text { SD) }\end{array}$ & $\begin{array}{r}\text { Treatment } \\
\text { (mean } \pm \text { SD) }\end{array}$ & $\begin{array}{c}\text { Control } \\
(\text { mean } \pm \text { SD) }\end{array}$ & $\begin{array}{c}\text { p value } \\
\text { (T vs. C only) }\end{array}$ \\
\hline TS (\%) & $14.53 \pm 0.17$ & $14.70 \pm 0.46$ & $14.65 \pm 0.49$ & $12.38 \pm 1.34$ & $13.23 \pm 0.59$ & 0.49 \\
\hline VS (\%) & $93.224 \pm 2.183$ & $95.323 \pm 1.551$ & $94.802 \pm 2.701$ & $91.687 \pm 0.346$ & $92.214 \pm 0.503$ & 0.209 \\
\hline $\begin{array}{l}\text { VS }>250 u m \\
(\%)\end{array}$ & $95.647 \pm 0.579$ & $96.270 \pm 1.175$ & $96.092 \pm 1.310$ & $93.677 \pm 1.142$ & $92.336 \pm 0.476$ & 0.0674 \\
\hline $\begin{array}{l}\text { VS }<250 u m \\
(\%)\end{array}$ & $89.665 \pm 4.749$ & $88.907 \pm 8.733$ & $90.217 \pm 7.824$ & $86.132 \pm 2.086$ & $91.889 \pm 3.293$ & $0.0314 *$ \\
\hline $\begin{array}{l}\mathrm{NH}_{4}{ }^{+}-\mathrm{N} \\
(\mathrm{mg} / \mathrm{kg})\end{array}$ & $402.0 \pm 58.5$ & N.A. & N.A. & $66.8 \pm 25.1$ & $<2.5$ & 0.011 \\
\hline $\begin{array}{l}\mathrm{NH}_{3}-\mathrm{N} \\
(\mathrm{mg} / \mathrm{kg})\end{array}$ & $24.3 \pm 8.2$ & N.A. & N.A. & $<2.5$ & $<2.5$ & N.A. \\
\hline $\mathrm{pH}$ & $8.04 \pm 0.17$ & $5.88 \pm 0.12$ & $6.53 \pm 0.21$ & $4.60 \pm 0.01$ & $6.56 \pm 0.30$ & $0.0074 *$ \\
\hline $\mathrm{NO}_{3}^{-}(\mathrm{mg} / \mathrm{kg})$ & $<2.5$ & $0.23 \pm 0.40$ & $<2.5$ & $22735 \pm 4741$ & $5078 \pm 2167$ & $0.0042 *$ \\
\hline TKN (mg/kg) & $34000 \pm 15400$ & $9600 \pm 2200$ & $16900 \pm 15600$ & $16700 \pm 4100$ & $19000 \pm 1500$ & 0.51 \\
\hline $\begin{array}{l}\text { E.coli } \\
\text { (CFU/g) }\end{array}$ & $61422 \pm 9042$ & $0^{++}$ & $18426 \pm 9042$ & $442 \pm 290$ & $310 \pm 360$ & 0.65 \\
\hline $\begin{array}{l}\text { Ascaris ova } \\
(\# / \mathrm{g})\end{array}$ & $2626 \pm 1306$ & $0^{++}$ & $787.8 \pm 1306$ & $6269 \pm 3226$ & $4638 \pm 3095$ & 0.56 \\
\hline $\begin{array}{l}\text { Ascaris } \\
\text { (\% viable) }\end{array}$ & $61.6 \pm 8.7$ & N.A. & $61.6 \pm 8.7$ & $52.7 \pm 8.4$ & $57.4 \pm 7.2$ & 0.50 \\
\hline $\mathrm{Zn}(\mathrm{mg} / \mathrm{kg})$ & $112.5 \pm 12.6$ & $0^{++}$ & $33.75 \pm 12.6$ & $45.6 \pm 11.2$ & $26.8 \pm 15.2$ & 0.17 \\
\hline $\mathrm{P}(\mathrm{mg} / \mathrm{kg})$ & $5833 \pm 1072$ & $285.7 \pm 321.9$ & $1949 \pm 1119$ & $2554 \pm 889$ & $3299 \pm 1527$ & 0.51 \\
\hline Cocoons (\#/g) & 0 & 0 & 0 & $0.069 \pm 0.087$ & 0 & N.A. \\
\hline Worms (\#) & 0 & 15 & 15 & $8.7 \pm 3.1$ & 0 & N.A. \\
\hline
\end{tabular}

+: Weighted average by wet weight of coir and feedstock added to each container

++ : Assumed, not measured.

N.A.: Not measured.

Table 3. Comparison of studies on the effects of vermicomposting on $\mathrm{pH}$, nitrate, total available nitrogen (TAN), and volatile solids (VS) or total organic carbon (TOC)

\begin{tabular}{|c|c|c|c|c|c|c|c|c|c|}
\hline \multirow[b]{2}{*}{ Source } & \multirow[b]{2}{*}{ Feedstock } & \multirow[b]{2}{*}{ Time } & \multicolumn{2}{|c|}{ pH } & \multicolumn{2}{|c|}{$\begin{array}{c}\text { Nitrate } \\
(\mathrm{mg} / \mathrm{kg} \mathrm{ds})\end{array}$} & \multicolumn{2}{|c|}{$\begin{array}{l}\text { Total Nitrogen } \\
\text { (units) }\end{array}$} & \multirow[t]{2}{*}{$\begin{array}{l}\text { Decreased VS } \\
\text { or TOC }\end{array}$} \\
\hline & & & Initial & Final & Initial & Final & Initial & Final & \\
\hline $\begin{array}{l}\text { Bajsa et al. } \\
\text { (2005) }\end{array}$ & Sludge & N.A. & 9.5 & 4.5 & 500 & 3750 & N.A. & N.A. & N.A. \\
\hline $\begin{array}{l}\text { Bajsa et al. } \\
\text { (2005) }\end{array}$ & Sludge and sawdust & N.A. & 8 & 4.5 & 2500 & 1750 & N.A. & N.A. & N.A. \\
\hline $\begin{array}{l}\text { Hill and } \\
\text { Baldwin } \\
(2012)\end{array}$ & $\begin{array}{l}\text { Source separated } \\
\text { fecal matter }\end{array}$ & $3 \pm 1$ years & N.A. & $7.4 \pm 0.3$ & N.A. & $\begin{array}{l}1961 \\
\pm 700\end{array}$ & N.A. & N.A. & Yes, $20-30 \%$ \\
\hline $\begin{array}{l}\text { Yadav et al. } \\
\quad(2010)\end{array}$ & $\begin{array}{l}\text { Source separated } \\
\text { fecal matter }\end{array}$ & $4 \mathrm{mo}$ & $5.3 \pm 0.2$ & $8.0 \pm 0.3$ & N.A. & N.A. & $\begin{array}{c}41 \\
(\mathrm{~g} / \mathrm{kg})\end{array}$ & $\begin{array}{c}28 \\
(\mathrm{~g} / \mathrm{kg})\end{array}$ & Yes, $48 \%$ VS \\
\hline $\begin{array}{l}\text { Kumar and } \\
\text { Shweta } \\
(2011)\end{array}$ & $\begin{array}{l}\text { Cow dung with other } \\
\text { amendments }\end{array}$ & 60 days & N.A. & N.A. & N.A. & N.A. & $0.73-0.86 \%$ & $1.0-1.4 \%$ & Yes, $2-4 \%$ \\
\hline $\begin{array}{l}\text { Sangwan et } \\
\text { al. (2008) }\end{array}$ & $\begin{array}{c}\text { Mixtures of cow } \\
\text { dung, biogas plant } \\
\text { slurry and press mud }\end{array}$ & 91 days & $7.4-8$ & $6.1-7.4$ & N.A. & N.A. & $\begin{array}{l}15-19 \\
(\mathrm{~g} / \mathrm{kg})\end{array}$ & $\begin{array}{l}21-27 \\
(\mathrm{~g} / \mathrm{kg})\end{array}$ & Yes, $7-12 \%$. \\
\hline This study & $\begin{array}{c}\text { Source separated } \\
\text { fecal matter and coir }\end{array}$ & 90 days & $6.5 \pm 0.2$ & $4.6 \pm 0.0$ & $<2.5$ & $\begin{array}{c}23000 \pm 4 \\
741\end{array}$ & $\begin{array}{l}17 \pm 16 \\
(\mathrm{~g} / \mathrm{kg})\end{array}$ & $\begin{array}{c}17 \pm 4 \\
(\mathrm{~g} / \mathrm{kg})\end{array}$ & N.A. \\
\hline
\end{tabular}


Vermicomposted material had a $\mathrm{pH}$ of $4.60 \pm 0.01$ which was significantly less than the control $(6.56 \pm 0.30)$ $(\mathrm{p}=0.0074)$ and lower than the feedstock $(8.04 \pm 0.17)$, coir $(5.88 \pm 0.12)$ and weighted average of the two $(6.53 \pm 0.21)$ (Table 2$)$. A wide range of vermicompost end product $\mathrm{pH}$ values have been reported and generally related to feedstock characteristics, as noted in Table 3. Eisenia sp. are suggested to have a $\mathrm{pH}$ preference as low as 5.0 (Dominguez \& Edwards, 2011) and as high as 7.0 (Sinha et al., 2009). The decrease in pH was expected for both the control and even more so for the treatment: decomposition produces organic acids and $\mathrm{CO}_{2}$, while nitrification (known to be amplified during vermicomposting) consumes hydroxide ions (Haug, 1993; Parkin \& Berry, 1999). A pH of 4.6 is too low for reuse of the end product as fertilizer and this would need to be raised by adding a neutralizing agent, such as lime.

When the feedstock and coir were mixed together, the total (weighted) average volatile solids (VS) percent was $94.8 \pm 2.7 \%$, which after 90 days was reduced to $91.7 \pm 0.35 \%$ in the vermicompost treatment and $92.2 \pm 0.5 \%$ in the control (Table 2). The treatment and control were not significantly different. However, when sieved through a $250 \mu \mathrm{m}$ screen, the fine fraction of starting material, treatment, and control VS values were all lower than the total VS values and as predicted, the vermicomposting VS was significantly lower than for the control (Table 2, $\mathrm{p}=0.0314$ ) indicating accelerated decomposition in the fine fraction. Conversely, in the fraction $>250 \mu \mathrm{m}$ the VS of the starting material, treatment and control were all higher than the total VS values, and the control almost had significantly less VS than the treatment $(92.3 \pm 0.5$ and $93.7 \pm 1.4)$, respectively $\mathrm{p}=0.0674)$ (Table 2). Large filamentous fungal growths were observed in the control jars of similar previous experiments (results not shown) Fungi are one of the main agents in decomposing large complex lignin particles and may have degraded this fraction faster in the controls where there was less predation by worms (Dominguez \& Edwards, 2011).

It is common in vermicomposting human fecal matter to see VS values decrease to $60-80 \%$ from starting values of $90 \%$ (Table 3), however, the significant results found here are likely to still have important functional meaning. The relatively small magnitude of VS reduction was likely due to a small fraction of biodegradable carbon, and a large fraction containing lignin, the majority of which was not biodegradable, yet incinerated at $500^{\circ} \mathrm{C}$ and dominated the VS result. Chandler et al. (1980) proposed Equation 1, which can be used to calculate the biodegradable fraction. Coconut coir has very high lignin content (30\%); and resulting decomposition can take many years (Anbuselvi, 2009). Applying the Chandler et al. (1980) equation to coir, the result is $-1 \%$; very little of coir's VS is thus biodegradable.

$$
B=0.830-(0.028) X
$$

Where $B$ is the biodegradable fraction of the VS and $X$ is the percent lignin content as \% fraction of the VS.

Coir was chosen as a bulking agent into which the Ascaris sp. inoculated fecal matter was placed in order to have worms preferentially consume fecal matter over bulking agent maximizing the ingestion of Ascaris sp. ova. The percent reduction in volatile solids as a result of vermicomposting can be estimated by dividing the recorded percent reduction in fine volatile solids between treatment and averaged starting material $(4.1 \pm 7.8 \%)$ by the wet weight ratio of fecal matter to coir $(0.3(30: 70))$ to remove the influence of coir and by the fraction of material $<250 \mu \mathrm{m}>250 \mu \mathrm{m}(0.40 \pm 0.14)$ to include only the fine fraction of material. The result is $34 \pm 8 \%$ reduction in volatile solids, bringing the reduction into a similar range found in other vermicomposting studies (Table 3 ).

The original VS reduction through vermicomposting may be even larger. A considerable fraction of the VS may have been turned into $\mathrm{CO}_{2}$ subsequently fixed into microbial mass by lithoautotrophic nitrifying bacteria. The nitrate content of the treatment material was very high $\left(22735 \pm 4741 \mathrm{mg} / \mathrm{kg} \mathrm{NO}_{3}{ }^{-}\right) ; 10-500$ times greater than previously reported for vermicomposts from human waste $\left(1750-3750 \mathrm{mg} / \mathrm{kg} \mathrm{NO}_{3}{ }^{-}\right.$) (Table 3 ) or by commercial compost quality standards ( $>50 \mathrm{mg} / \mathrm{kg} \mathrm{NO}_{3}{ }^{-} \mathrm{N}$ ) (Wichuk \& McCartney, 2010).

The high level of nitrate found in the vermicomposted material (5 $078 \pm 2167 \mathrm{mg} / \mathrm{kg} \mathrm{NO}_{3}{ }^{-}$) was significantly greater than that of the control $(\mathrm{p}=0.0042)$ both of which were greater than the starting material, which was below the detection limit (Table 2). Nitrate is produced by aerobic lithotrophic bacteria and archaea through the oxidation of ammonium (Haug, 1993). This is the rate-limiting step in the nitrogen cycle due to the high oxygen demand (amongst other limiting factors) of these microbes $\left(\sim 4 \mathrm{~g} \mathrm{O}_{2} / \mathrm{g}-\mathrm{NH}_{3}-\mathrm{N}\right)$, which can prevent complete conversion of all available nitrogen to nitrate. Comparing the total nitrogen $(16700 \pm 4100 \mathrm{mg} / \mathrm{kg}$ ) to nitrate (22 $735 \pm 4741 \mathrm{mg} / \mathrm{kg} \mathrm{NO}_{3}{ }^{-}$) in the treatment, it appears that complete nitrification took place. Whereas only one quarter of the TKN (19 000 $1500 \mathrm{mg} / \mathrm{kg}$ ) was converted to nitrate $(5078 \pm 2167 \mathrm{mg} / \mathrm{kg})$ in the control. There is ample supporting evidence for significantly increased mineralization rates, high nitrate content, and nitrifying microbial mass associated with earthworm activity in burrows (Parkin \& Berry, 1999) and in vermicomposting operations (Subler, Edwards, \& Metzger (1998); Dominguez \& Edwards, 2011). There is also research indicating that coir is an excellent medium for nitrifying bacteria (Reghuvaran \& Das Ravindranath, 2010). 
Indeed, based on relative $\log _{2}\{-\operatorname{Delta}(\mathrm{Cq})\}$ values from the qPCR analysis, the ratio of bacterial ammonium oxidizing genes $(A m o A)$ to total bacteria DNA (16S rDNA) was 40 times larger in the vermicomposting treatment as compared to the control $(\mathrm{p}<0.01)$ (Figure 1). Vermicomposting human waste with coir may be a highly effective process for the production of nitrate fertilizer.

The small amounts of ammonium-N found in the treatment $(66.8 \pm 25.1 \mathrm{mg} / \mathrm{kg})$ may have resulted from recent worm death and decay, which was not present in the controls. It is not known if there was any ammonium-N in the coir since it was not measured. The coir was well aerated before being used in the experiment and likely did not contain enough ammonium-N to have an impact on Ascaris inactivation. There was no significant difference in zinc or potassium between treatment and control and no trend compared to starting material (Table 2).

Our results indicate no difference in Ascaris sp. concentration $(\mathrm{p}=0.56)$ or viability $(\mathrm{p}=0.50)$ between treatment and control and no reduction in viability after 90 days compared to initial feedstock (Table 2). It appears as though concentrations of ova are greater in the treatment and control than in the feedstock, and while this may be due to loss of organic matter from decomposition, it was not a significant effect and the variability was likely caused by incomplete mixing during inoculation.

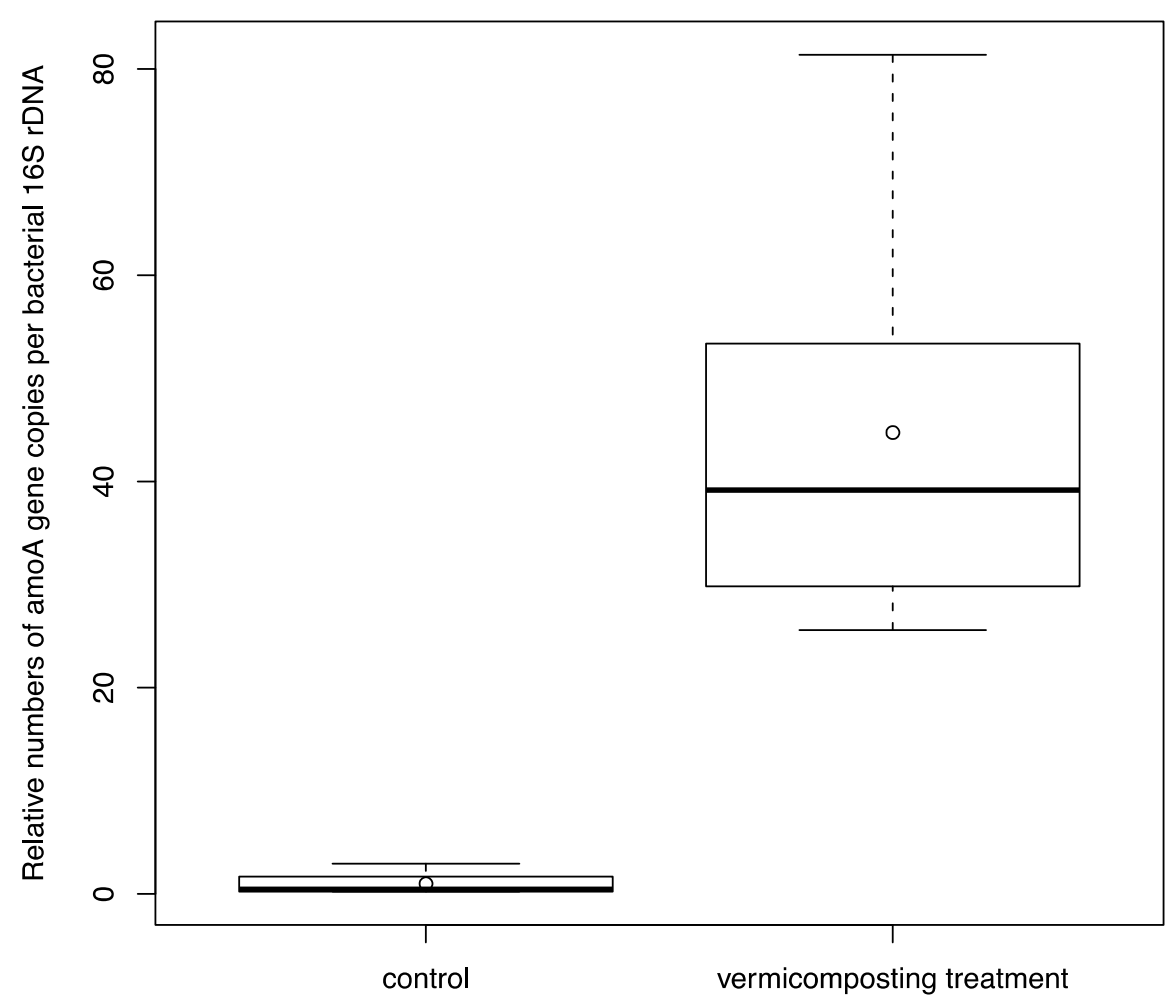

Figure 1. Numbers of bacterial ammonia oxidation genes $(\mathrm{amoA})$ relative to the total bacterial $16 \mathrm{~S}$ rDNA in the control and vermicomposting end product samples as determined by qPCR of the respective genes. Top and bottom whiskers represent the maximum and minimum values, respectively; the box, the first and third quartiles; the thick horizontal line, the median; and the open circle, the mean

E. coli was reduced from a starting concentration of $6.1 \times 10^{4} \mathrm{CFU} / \mathrm{g}$ to $<1000 \mathrm{CFU} / \mathrm{g}$ in both treatment and control but no differences were found between treatment and control and no conclusions can be drawn in regards to the efficacy of vermicomposting on bacterial pathogens. A considerable number of studies have been conducted on bacterial pathogen destruction resulting from vermicomposting, the vast majority of which indicate more rapid and complete bacterial pathogen destruction than a control lacking earthworms (Mitchell, 1978; Brown \& Mitchell, 1981; Eastman et al., 2001). More importantly, E. coli concentration had no correlation to Ascaris sp. viability indicating that E. coli elimination alone cannot be proof of sanitation through vermicomposting. 
Due to the high lignin content of the coir, it is not possible to assume all matter and ova in the jars was ingested. However, it is also unrealistic to rely on worms to consume the material completely enough to be assured $4 \log _{10}$ reduction in Ascaris ova and meet WHO guidelines ((WHO), 2006) for unrestricted use $\left(10^{4} \mathrm{ova} / \mathrm{g}\right.$ reduced to 1 ova/g). Moreover, ingestion of ova by Lumbricus terrestris appears to have little effect on Ascaris sp. ova (Rysavy, 1969). The lack of ova reduction despite a full range of biochemical effects brought about by vermicomposting casts doubt on the efficacy of pathogen destruction processes.

The data presented here should help to clarify some debate on the topic of Ascaris sp. ova destruction through vermicomposting. Eastman et al. (2001) report significant helminth ova reduction from $8.26 \times 10^{5} \mathrm{ova} / 4 \mathrm{~g}(\mathrm{dw})$ to $9.33 \pm 1.45 \times 10^{3}$ in 6 days through windrow vermicomposting with Eisenia sp. as compared to $2.16 \pm 0.18 \times 10^{5}$ windrow composting without earthworms. However, as Bowman et al. (2006) point out, some aspects of Eastman et al. (2001) experimental design and analyses appeared to be flawed. Eastman et al. (2001) report inoculating $1 \times 10^{6}$ ova into the windrow, estimated to be $531 \mathrm{~kg}$ of raw material (which should result in an average concentration of $2 \mathrm{ova} /$ gram), yet contradictorily report sampling $2 \times 10^{5} \mathrm{ova} / \mathrm{gram}$ at the start of the test. Eastman et al. (2001) also report adding 1:1.5 earthworm mass:biosolids mass. It seems unlikely that hundreds of kilograms of earthworms could be sourced, let alone transported and applied. Bowman et al. (2006) also found flaws with Cardosa and Ramirez (2002) who reported successful helminth ova destruction by vermicomposting to acceptable limits ( $<1 \mathrm{ova} / 4 \mathrm{~g}$ end product) yet fail to mention that starting concentrations of ova were also below this limit.

Bowman et al. (2006) conducted similar experiments using Ascaris sp. ova spiked potting soil, treatments with worms, and controls without worms and found similar results: No reduction in Ascaris sp. concentration was found after 183 days vermicomposting and no reduction in ova viability between vermicomposting and a control after 7 days and less than a 1 log reduction after 6 months.

It is concluded that additional treatment is necessary to ensure the destruction of Ascaris ova, as the vermicomposting process does not appear to have the capacity to do this. Post-treatment with urea and ash to elevate ammonia concentrations, as per McKinley, Parzen and Guzmán (2012b), should accomplish the desired sanitization step. While vermicomposting was shown here failing to accomplish complete sanitization, it can be relied upon as a low cost method to stabilize and mature fecal matter; processes which are both valuable in the practical aspects of waste management and essential in the development of compost suitable and beneficial when reused. Vermicomposing is also very useful for stabilization and increasing the nitrate content of the end product increasing its value as a fertilizer, if desired.

\section{Conclusions}

Vermicomposting was sustained for 90 days. In comparison to controls without earthworms, vermicomposting significantly increased nitrate, lowered $\mathrm{pH}$ and reduced volatile solids. Despite reduction in E. coli from 60000 to $<1000 \mathrm{CFU} / \mathrm{g}$ (ds) in both treatment and control, no reduction in Ascaris suum egg concentration or viability was found. These results indicate that the previously postulated pathogen destruction by selective grazing and extracellular biochemical process associated with vermicomposting have no effect on Ascaris suum ova concentration or viability.

\section{Acknowledgements}

Support for this research project was provided by BEES (Alpine Club of Canada), the American Alpine Club, Metro Vancouver, Natural Sciences and Engineering Research Council (Post Graduate Scholarship to GBH; Discovery Grant to SAB), Mountain Equipment COOP, British Columbia Community Legacy Program, and the UBC Alma Mater Society.

\section{References}

Anbuselvi, S. (2009). Study on biodegradation of coir waste by cyanobacteria and comparing its efficiency with different organic manures on blackgram varieties. PhD. Bharath University

Bajsa, O., Nair, J., Mathew, K., \& Ho, G. (2003). Vermiculture as a tool for domestic wastewater management. Water Science and Technology, 48(11-12), 125-132.

Bean, C., Hansen, J., \& Margolin, A. (2007). Class B alkaline stabilization to schieve pathogen inactivation. International Journal of Environmental Research and Public Health, 4(1), 53-60. http://dx.doi.org/10.3390/ijerph2007010009 PMid:17431316

Benitez, E., Nogales, R., Elvira, C., Masciandaro, G., \& Ceccaniti, B. (1999). Enzyme activities as indicators of the stabilization of sewage sludges composting with Eisenia foetida. Bioresource Technology, 67, 297-303. 
http://dx.doi.org/10.1016/S0960-8524(98)00117-5

Bowman, D. D., Liotta, J. L., McIntosh, M., \& Lucio-Forster, A. (2006). Ascaris suum Egg Inactivation and Destruction by the Vermicomposting Worm, Eisenia foetida. Residuals and Biosolids Management. Bridging to the Future, Water Environment Federation.

Brown, B. A., \& Mitchell, M. J. (1981). Role of the earthworm, Eisenia foetida, in affecting survival of Salmonella enteritidis ser. typhimurium. Pedobiologia, 22, 434-438.

Cardosa, V. L., \& Ramirez, C. E. (2002). Vermicomposting of sewage sludge: A new technology for Mexico. Water, Science and Technology, 46, 153-158.

Chandler, J. A., Jewell, W. J., Gossett, J. M., Soest, P. J. V., \& Robertson., J. B. (1980). Predicting methane fermentation biodegradability. New York: John Wiley \& Sons, Inc.

Del Porto, D., \& Steinfeld, C. (2000). Composting Toilet System Book: A Practical Guide Pollution to Choosing, Planning, and Maintaining Composting Toilet Systems. Concord, MA: Center of Ecological Pollution Prevention.

Dominguez, J., \& Edwards, C. A. (2011). Biology and ecology of earthworm species used for vermicomposting. In C. A. Edwards, N. Q. Arancon, \& R. Sherman (Eds.), Vermiculture Technology (pp. 249-261). Florida: CRC Press Taylor and Francis Group.

Domínguez, J., \& Edwards, C. A. (1997). Effects of stocking rate and moisture content on the growth and maturation of Eisenia andrei (Oligochaeta) in pig manure. Soil Biology and Biochemistry, 29, 743-746. http://dx.doi.org/10.1016/S0038-0717(96)00276-3

Eastman, B. R., Kane, P. N., Edwards, C. A., Trytek, L., Gunadi, B., Stermer, A. L., \& Mobley, J. R. (2001). The effectiveness of vermiculture in human pathogen reduction for USEPA biosolids stabilization. Compost Science and Utilization, 9(1), 38-49.

Edwards, C. A., Arancon, N. Q., \& Sherman, R. (2011). Vermiculture Technology. Florida: CRC Press Taylor and Francis Group.

Edwards, C. A., \& Bohlen, P. J. (1996). Biology and Ecology of Earthworms. London, UK: Chapman and Hall.

Edwards, C. A., \& Subler, S. (2011). Human pathogen reduction during vermicomposting. In C. A. Edwards, N. Q. Arancon, \& R. Sherman (Eds.), Vermiculture Technology (pp. 249-261). Florida: CRC Press Taylor and Francis Group.

Gantzer, C., Gaspard, P., \& Galvez, L. (2001). Monitoring of bacterial and parasitological contamination during various treatment of sludge. Water Research, 35(16), 3763-3770. http://dx.doi.org/10.1016/S0043-1354(01)00105-1

Haug, R. T. (1993). The Practical Handbook of Compost Engineering. Florida: Lewis Publishers.

Hill, G. B., \& Baldwin, S. A. (2012). Vermicomposting toilets, an alternative to latrine style microbial composting toilets, prove far superior in mass reduction, pathogen destruction, compost quality, and operational cost. Waste Management, 32(10), 1811-20. http://dx.doi.org/10.1016/j.wasman.2012.04.023

Jimenez-Cisneros, B. E., \& Maya-Rendon, C. (2007). Helminths and sanitation. In Méndez-Vilas, A. (Ed.), Communicating Current Research and Educational Topics and Trends in Applied Microbiology, 1 (pp. 60-71). http://www.formatex.org/microbio/

Kato, S., Fogarty, E., \& Bowman, D. D. (2003). Effect of aerobic and anaerobic digestion on the viability of Cryptosporidium parvum oocysts and Ascaris suum eggs. International Journal of Environmental Health Research, 13(2), 169-179. http://dx.doi.org/10.1080/0960312031000098071

Kumar, R., \& Shweta (2011). Removal of pathogens during vermi-stabilization. Journal of Environmental Science and Technology, 4(6), 621-629. http://dx.doi.org/10.3923/jest.2011.621.629

Lane, D. J., Pace, B., Olsen, G., Stahl, D., Sogin, M., \& Pace, N. (1985). Rapid determination of 16S ribosomal RNA sequences for phylogenetic analyses. PNAS, 82(20), 6955-6959. http://dx.doi.org/10.1073/pnas.82.20.695

McKinley, J. W., Parzen, R. E., \& Guzmán, A. M. (2012). Impact of climate and bulking materials on characteristics of compost from ecological toilets. Journal of Water, Sanitation and Hygiene for Development, 2(2), 79-86. http://dx.doi.org/10.2166/washdev.2012.059

McKinley, W., Parzen, R. E., \& Guzmán, M. A. (2012b). Ammonia Inactivation of Ascaris Ova in Ecological 
Compost Using Urine and Ash. Applied and Environmental Microbiology, published ahead of print $11 \mathrm{My}$ 2012.

Mendez-Contreras, J., Jimenez, B., \& Maya, C. (2004). Disinfection kinetics of pathogens in physiochemical sludge treated with ammonia. Water Science and Technology, 50(9), 67-74.

Mitchell, M. J. (1978). Role of invertebrates and microorganisms in sludge decomposition. In R. Hartenstein, \& V. A. Springeld (Eds.), Utilization of Soil Organisms in Sludge Management, PB286932 (pp. 35-50). Springfield, VT: The National Technology Information Service.

Neuhauser, E. F., Loehr, R. C., \& Malecki, M. R. (1988). The potential of earthworms for managing sewage sludge. In C. A. Edwards, \& E. F. Neuhauser (Eds.), Earthworms in Waste and Environmental Management (pp. 9-20). Den Hague, The Netherlands: SPB Academic Publishing.

Parkin, T. B., \& Berry, E. C. (1999). Microbial nitrogen transformations in earthworm burrows. Soil Biology and Biochemistry, 31, 1765 1771 .

Reghuvaran, A., \& Das Ravindranath, A. (2010). Efficacy of biodegraded coir pith for cultivation of medicinal plants. Journal of Scientific and Industrial Research, 69(7), 554-559.

Rotthauwe, J. H., Witzel, K. P., \& Liesack, W. (1997). The ammonia monooxygenase structural gene amoA as a functional marker: Molecular fine-scale analysis of natural ammonia-oxidizing populations. Applied and Environmental Microbiology, 63(12), 4704-4712.

Rysavy, B. (1969). Lumbricidae - an important parasitological factor in helminthoses of domestic and wild animals. Pedobiologia, 9, 171-174.

Sangwan, P., Kaushik, C. P., \& Garg, V. K. (2008). Vermiconversion of industrial sludge for recycling the nutrients. Bioresource Technology, 99, 8699-8704. http://dx.doi.org/10.1016/j.biortech.2008.04.022

Sinha, R. K., Herat, S., \& Bharambe, G. A. B. (2009). Vermistabilization of sewage sludge (biosolids) by earthworms: converting a potential biohazard destined for landfill disposal into a pathogen-free, nutritive and safe biofertilizer for farms. Waste Management \& Research, 28, 872-881 http://dx.doi.org/10.1177/0734242X09342147

Subler, S., Edwards, C., \& Metzger, J. (1998). Comparing vermicomposts and composts. Biocycle, 39(7), 63-66.

Watson, M., Wolf, A., \& Wolf, N. (2003). Total Nitrogen. In J. Peters (Ed.), Recommended Methods of Manure Analysis. A3769 (pp. 18-24). University of Wisconsin-extension.

(WHO), W. H. O. (2006). WHO GUIDELINES FOR THE SAFE USE OF WASTEWATER, EXCRETA AND GREYWATER. Geneva, Switzerland, World Health Organization (WHO).

Wichuk, K. M., \& McCartney, D. (2010). Compost stability and maturity evaluation- a literature review. Canadian Journal of Civil Engineering, 37, 1505-1523. http://dx.doi.org/10.1139/L10-101

Wood, M. (1995). Environmental Soil Biology. Bishopbriggs, Glasgow: Blackie Academic \& Professional. http://dx.doi.org/10.1007/978-94-011-0625-2

Yadav, K. D., Hait, S., \& Tare, V. (2007). Source separation techniques for recovery of nutrients from human excreta. World Toilet Summit. New Delhi, India. 